\title{
Altering undigested neutral detergent fiber through additives applied in corn, whole barley crop, and alfalfa silages, and its effect on performance of lactating Holstein dairy cows
}

\author{
Seyed Mohsen Hosseini ${ }^{1}$, Mohsen Danesh Mesgaran ${ }^{1, *}$, Ali Reza Vakili ${ }^{1}$, \\ Abbas Ali Naserian', and Ehsan Khafipour ${ }^{2}$
}

\author{
* Corresponding Author: Mohsen Danesh Mesgaran \\ Tel: +98-513-880-2000, Fax: +98-511-8787430, \\ E-mail: danesh@um.ac.ir \\ 'Department of Animal Science, Faculty of Agriculture, \\ Ferdowsi University of Mashhad, P.O. Box 91775- \\ 1163, Mashhad, Iran \\ 2 Department of Animal Science, University of \\ Manitoba, Winnipeg, Manitoba, R3T 2N2, Canada \\ ORCID \\ Seyed Mohsen Hosseini \\ https://orcid.org/0000-0002-7838-4062 \\ Mohsen Danesh Mesgaran \\ https://orcid.org/0000-0002-2738-5284 \\ Ali Reza Vakili \\ https://orcid.org/0000-0001-7862-9763 \\ Abbas Ali Naserian \\ https://orcid.org/0000-0003-1179-6262 \\ Ehsan Khafipour \\ https://orcid.org/0000-0003-4673-7633
}

Submitted Apr 23, 2018; Revised Jun 8, 2018; Accepted Jul 5, 2018
Objective: We hypothesized that silage additives may alter the undigested neutral detergent fiber (uNDF) content through ensiling. Therefore, urea and formic acid were applied to corn, whole barley crop (WBC) and alfalfa to change uNDF content of the ensiled forages.

Methods: Six experimental diets at two groups of high uNDF (untreated corn and alfalfa silages [CSAS] and untreated whole barley and alfalfa silages [BSAS]) and low uNDF (ureatreated corn silage+untreated alfalfa silage $\left[\mathrm{CS}_{\mathrm{U}} \mathrm{AS}\right]$, urea-treated whole barley silage+untreated alfalfa silage $\left[\mathrm{BS}_{\mathrm{U}} \mathrm{AS}\right]$, untreated corn silage+formic acid-treated alfalfa silage $\left[\mathrm{CSAS}_{\mathrm{F}}\right]$, and untreated whole barley silage+formic acid-treated alfalfa silage $\left.\left[\mathrm{BSAS}_{\mathrm{F}}\right]\right)$, were allocated to thirty-six multiparous lactating Holstein dairy cows.

Results: The untreated silages were higher in UNDF than additive treated silages, but the $\mathrm{uNDF}$ concentrations among silages were variable (corn silage $<$ barley silage $<$ alfalfa silage). Dry matter intake was not influenced by the reduction of uNDF or physical NDF supply source from corn to WBC silages ( $\mathrm{p}>0.05$ ). Milk yield tended to increase in the cows fed high $\mathrm{uNDF}$ diets than those fed low uNDF $(\mathrm{p}=0.10)$. The cows fed diet based on urea-treated corn silage had higher milk yield than those fed other silages $(\mathrm{p}=0.05)$. The substitution of corn silage with the WBC silage tended to decrease milk production $(\mathrm{p}=0.07)$. Changing the physical source of NDF supply and the uNDF content from the corn silage to the WBC silage caused a significant increase in ruminal $\mathrm{NH}_{3}-\mathrm{N}$ concentration, milk urea- $\mathrm{N}$ and fat yield ( $\mathrm{p}<$ $0.05)$. The cows fed diets based on WBC silage experienced greater rumination time than the cows fed corn silage $(\mathrm{p}<0.05)$.

Conclusion: Administering additives to silages to reduce UNDF may improve the performance of Holstein dairy cows.

Keywords: Corn; Whole Barley Crop; Alfalfa; Undigested Neutral Detergent Fiber; Milk; Cow

\section{INTRODUCTION}

Silages have become the necessary forage component in the ration of dairy cows over the last few decades [1]. They are often a wise choice when selecting forages for providing fiber and energy needed to optimize rumen function [2]. A critical component for assessing of silage quality is fiber digestibility that impact on feed intake and milk yield [2]. Silage digestibility, which is a complex function, is related to the dynamic processes of degradation and passage rate from the rumen [3]. A 0.01 unit increase in neutral detergent fiber (NDF) degradability cause an increase in daily intake of $0.17 \mathrm{~kg}$ and fat-corrected milk (FCM) with 0.25 $\mathrm{kg} / \mathrm{d}$ [4]. Raffrenato and Van Amburgh [5] noted that fiber digestibility relates to two digestible pools, followed the first order kinetic, but each has a different rate of digestion; fast digestion 
was defined at 24 to $30 \mathrm{~h}$ and slow digestion at 96 to $120 \mathrm{~h}$. Undigested NDF (uNDF) defined as the functional fiber fraction that influences physical effectiveness, gut fill, potential microbial protein from digested NDF in the rumen, and digestion/passage dynamics of forage samples [6]. The uNDF of a feed is a better analytical indicator of nutritional availability than either NDF digestibility or NDF because UNDF can be used to predict potentially digestible NDF (pdNDF; defined as NDF - uNDF), estimated the NDF pools and rates of fiber fermentation, influenced dry matter intake (DMI) and chewing response. Therefore, any process in the silage that changes NDF digestion or UNDF content may affect the performance of an animal [7]. Silage additives have been used to enhance the ensiling fermentation by preventing the production of undesired acids to produce well-preserved silages [8]. Urea is a synthetic, non-protein nitrogen compound classified as a nutrient silage additive, because it is a source of nitrogen for bacteria in the rumen [9]. It seemed that corn silage (a high energy, low protein feed) might be an ideal type of feed to be considered for use with urea as an additive to increase its crude protein content. Formic acid, as an inhibitor of fermentation and for its antibacterial effect is an organic acid cause a reduction in protein degradation and deamination in legume such as alfalfa [10] and improves animal performance [11,9]. Cushnahan and Mayne [12] showed no effect of restricting silage fermentation on NDF digestibility. In contrast, Weimer [7] suggested that the buffering effect of silage additive on rumen $\mathrm{pH}$ might be a possible explanation for the beneficial effects on fiber digestibility. However, there has been limited literature or research on the evaluation of silage based on fiber digestion and uNDF. In this study, we hypothesized that i) Inclusion of additives during ensiling improve fermentation characteristics, ii) Additives influence fiber digestion and decrease uNDF by changing silage chemical properties followed by increasing milk yield and milk composition, and iii) Corn and whole barley crop (WBC) silages have different responses to performance and chewing activity owing to various intrinsic uNDF and physical breakdown. Therefore, the aim of the present study was first to evaluate the effects of urea and formic acid applied in corn, WBC and alfalfa silages in an effort to alter uNDF using in vitro incubation with buffered rumen fluid. Then, to investigate the effect of uNDF in lactating Holstein dairy cow diets on performance, ruminal characteristics, chewing activity and selected blood metabolites.

\section{MATERIALS AND METHODS}

\section{Silages management, animals and feeds}

The corn forage (hybrid 700) on 17 September 2016 at 2/3 milk line of kernel maturity stage, WBC (Hordeum vulgare L.) on 20 April 2016 at dough stage, and alfalfa forage (Medicago sativa L.) on 10 May 2016 in second cutting at $40 \%$ flowering from a single field were harvested and chopped using a pulltype chopper (model 965, Claas, Omaha, NE, USA). Then, they were assigned to two groups of untreated and treated with urea at $21.6 \mathrm{~g} / \mathrm{kg}$ based on dry matter (DM) for corn and whole barley and formic acid at $4.4 \mathrm{~L} /$ ton of fresh alfalfa (10\% higher of founding Nagel and Broderick [13]) and ensiled for 40 days in trench silos (approximately 10 ton per each silo), sealed with two layers of plastic sheeting. Silage samples were individually evaluated using in vitro incubation [14] to determine undigested NDF (uNDF). The uNDF was evaluated at intervals of 30 (fast pool), 120 (slow pool), and 240 hours $\left(\mathrm{uNDF}_{30 \mathrm{~h}}, \mathrm{uNDF}_{120 \mathrm{~h}}\right.$, and $\mathrm{uNDF}_{240 \mathrm{~h}}$, respectively). Buffered rumen fluid preparation and procedure have been fully described by Raffrenato and Van Amburgh [5]. Briefly, rumen fluid was obtained from two rumen fistulated Holstein steers ( $310 \pm 11 \mathrm{~kg}$ body weight [BW], $11 \pm 0.3$ month age) which fed $2.1 \mathrm{~kg}$ of DM alfalfa hay, $3.2 \mathrm{~kg}$ of DM corn silage and $2.5 \mathrm{~kg}$ of DM concentrate plus supplemental vitamins and minerals (158 g crude protein [CP]/kg of DM). Rumen fluid and digesta were mixed with a blender, clarified through four layers of cheesecloth and strained through a nylon fabric with $46 \mu \mathrm{m}$ pore size. Exactly $500 \mathrm{mg}$ of ground silage samples were placed into a $120 \mathrm{~mL}$ glass bottle and then, $40 \mathrm{~mL}$ buffer accompanied by $10 \mathrm{~mL}$ of rumen fluid was added to each in triplicate with three runs. The samples that fermented longer than 120 hours were re-inoculated with the same amount of the initial rumen liquor/medium mix, as mentioned in Raffrenato and Van Amburgh [5]. At the end of fermentation, according to the specific time intervals, residue was analyzed to determine NDF content according to Van Soest et al [15]. The silages were included in the experimental diets $(n=6)$ to achieve high and low uNDF concentrations. Therefore, in high uNDF diets the untreated corn and alfalfa silages (CSAS) and untreated whole barley and alfalfa silages (BSAS) were used. While in low uNDF diets we used urea-treated corn silage+ untreated alfalfa silage $\left(\mathrm{CS}_{U} \mathrm{AS}\right)$, urea-treated whole barley silage+untreated alfalfa silage $\left(\mathrm{BS}_{U} \mathrm{AS}\right)$, untreated corn silage+ formic acid-treated alfalfa silage $\left(\mathrm{CSAS}_{\mathrm{F}}\right)$ and untreated whole barley silage+formic acid-treated alfalfa silage $\left(\mathrm{BSAS}_{\mathrm{F}}\right)$. All diets were formulated iso-nitrogenous and iso-energetic to meet all nutritional requirements of the dairy cows as described by the National Research Council ([16]; Table 1). All concentrates and alfalfa hay put aside to ensure all diet ingredient used in ration was a similar nutritional content thorough of trial. The pen state particle size separator was used for determined silage theoretical cutting length (Table 2; [17]). Thirtysix multiparous Holstein dairy cows in mid-lactation (590 \pm 7 kg BW; means \pm standard deviation) averaging $200 \pm 14$ days in milk and producing $29 \pm 4 \mathrm{~kg} / \mathrm{d}$ of milk were allocated into six groups (each group contained 6 cows) thorough of this trial. Experimental period lasted 56 days with the first 14 days pre-treatment for adaptation period followed by 42 days for 
Table 1. Ingredients (\% DM) and nutrient composition of dietary treatments

\begin{tabular}{|c|c|c|c|c|c|c|}
\hline \multirow{2}{*}{ Items } & \multicolumn{6}{|c|}{ Treatments $^{1)}$} \\
\hline & CSAS & CSUAS & CSASF & BSAS & BSUAS & BSASF \\
\hline \multicolumn{7}{|l|}{ Ingredients } \\
\hline Urea treated corn silage & - & 17.8 & - & - & - & - \\
\hline Untreated barley silage & - & - & - & 17.8 & - & 17.8 \\
\hline Urea treated barley silage & - & - & - & - & 17.6 & - \\
\hline Formic acid treated alfalfa silage & - & - & 14.7 & - & - & 14.9 \\
\hline Alfalfa hay & 7.8 & 7.8 & 7.8 & 7.94 & 7.9 & 7.94 \\
\hline Corn grain & 16.4 & 16.2 & 16.4 & 16.7 & 16.7 & 16.7 \\
\hline Barley grain & 17 & 17 & 17 & 17.3 & 17.3 & 17.3 \\
\hline Soybean meal $44 \%$ CP & 13.9 & 14.5 & 13.8 & 14.07 & 13.8 & 14.0 \\
\hline Vitamin-mineral $^{2)}$ & 0.78 & 0.78 & 0.78 & 0.79 & 0.79 & 0.79 \\
\hline Calcium phosphate (Di-) & 0.78 & 0.78 & 0.78 & 0.79 & 0.79 & 0.79 \\
\hline Magnesium oxide & 0.39 & 0.39 & 0.39 & 0.39 & 0.39 & 0.39 \\
\hline \multicolumn{7}{|l|}{ Chemical composition } \\
\hline $\mathrm{CP}(\%$ of $\mathrm{DM})$ & 16.2 & 16.1 & 16.2 & 16.2 & 16.3 & 16.4 \\
\hline $\mathrm{NFC}^{3)}(\%$ of $\mathrm{DM})$ & 42.6 & 42.6 & 42.6 & 41.7 & 41.7 & 41.7 \\
\hline NDF ( $\%$ of DM) & 31.4 & 31.2 & 31.3 & 31.9 & 31.7 & 31.6 \\
\hline ADF (\% of DM) & 18.9 & 18.9 & 18.9 & 18.9 & 18.9 & 18.9 \\
\hline Forage NDF ( $\%$ of DM) & 20.8 & 20.8 & 20.8 & 21 & 21 & 21 \\
\hline Ether extract ( $\%$ of DM) & 4.1 & 4.1 & 4.1 & 4.3 & 4.3 & 4.3 \\
\hline
\end{tabular}

DM, dry matter; CP, crude protein; NFC, non-fiber carbohydrate; NDF, neutral detergent fiber; ADF, acid detergent fiber; NEL, net energy for lactation.

1) CSAS, untreated corn and alfalfa silages; CS AS, urea-treated corn silage+untreated alfalfa silage; $C_{U} A S_{F}$ untreated corn silage+formic acid-treated alfalfa silage; BSAS, untreated barley and alfalfa silages; $\mathrm{BS}_{\mathrm{U}} \mathrm{AS}$, urea-treated barley silage+untreated alfalfa silage; $\mathrm{BSAS}_{\mathrm{F}}$ untreated barley silage+formic acid-treated alfalfa silage.

${ }^{2)}$ Supplied $0.7 \% \mathrm{Ca}, 0.6 \% \mathrm{P}, 36 \mathrm{mg} / \mathrm{kg} \mathrm{Cu}$, as well as vitamin $\mathrm{A}(3,000 \mathrm{lU} / \mathrm{kg})$, vitamin D (800 IU/kg), and vitamin E (6 IU/kg).

${ }^{3)}$ Calculated by difference $100-(\%$ NDF+ $\%$ CP+\% fat+\% ash).

sampling. Animals were cared and the Iranian Institutional Animal Care Committee [18] approved the experiment for animals used in research. The cows were housed in a tie stall barn covered by a roof in individual pens measuring $1.10 \times 2.50$ and each cow stayed in its own pen thorough of the trial. The cows had free access to water and were fed ad libitum and received feed second times a day at 0800 and 1600 directly

Table 2. Particle size distribution of corn and WBC silage used in diets by pen state particle size separator

\begin{tabular}{lcc}
\hline Items & Corn silage & WBC silage \\
\hline \% DM retained on sieve & & \\
$>19.00 \mathrm{~mm}$ & 25.3 & 30.3 \\
19.0 to $8.0 \mathrm{~mm}$ & 57.8 & 59.5 \\
8.0 to $1.18 \mathrm{~mm}$ & 15.8 & 9.2 \\
$<1.18 \mathrm{~mm}$ & 1.1 & 1 \\
$X_{\text {gm }}(\mathrm{mm})$ & 12.32 & 14.05 \\
Standard deviation & 2.06 & 2.11 \\
\hline
\end{tabular}

WBC, whole barley crop; DM, dry matter. after milking. The feed allocated was increased or decreased with feed intake, until a $10 \%$ residue was achieved. The cows were allowed $10 \mathrm{~min}$ of exercise, three times daily.

\section{Recordings and sampling}

After opening the plastic silos, four representative samples of the fresh silages of corn, WBC and alfalfa were collected from different part for determination of $\mathrm{pH}, \mathrm{NH}_{3}-\mathrm{N}$ concentration and chemical composition. In sampling period, DMI was determined as the difference between total mixed ration (TMR) offered and orts weighed daily, then samples of orts collected and pooled per cow for the determination of chemical composition. The cows were weighed at the beginning and the end of the experimental period. The milk production was electronically recorded daily, at each individual milking, through the experiment. Milk samples were taken every week and sent to the Dairy Laboratory for the determination of milk composition. Milk composition was calculated as an average of morning and afternoon samples using the proportion of daily 
production at that milking as a weighting factor. Blood samples were collected at 07:00 am before the morning feeding from the jugular vein into two evacuated serum tubes containing clot activator (BD Vacationer Systems; Becton, Dickinson and Company, Franklin Lakes, NJ, USA). All blood samples were transported to the lab in an ice bucket, and serum was separated by centrifugation at $1,600 \times \mathrm{g}$ and $4^{\circ} \mathrm{C}$ for $15 \mathrm{~min}$, and then stored at $-20^{\circ} \mathrm{C}$ until assaying of glucose, total cholesterol, alanine aminotransferase, aspartate aminotransferase (AST), and blood urea-N. The fecal samples were collected directly from the rectum once daily at noon on the last five consecutive days and pooled per cow. Then they were stored at $-20^{\circ} \mathrm{C}$, until chemical analysis. Apparent total tract digestibility coefficients were determined by acid insoluble ash technique (AIA) as an internal marker $[19,20]$. At the end of period, rumination activity was monitored for every cow over a $24 \mathrm{~h}$ visually (one expert person was considered for every 12 cows). Eating, ruminating and water consumption activities were recorded at 5-min intervals, and each activity was assumed to persist during the entire 5 min interval [21]. A body condition score was performed during afternoon milking. A score 1 to 5 was given to each cow, one indicating severe under nutrition and five indicates sever obesity [22]. Body surface temperatures were collected in order to assess differences in body temperature among cows at the end of experimental period. Body surface temperatures of each cow recorded using a thermal imaging camera (Fluke Ti25 Infrared Camera; Fluke Corporation, Everett, WA, USA). At the end of period, $4 \mathrm{~h}$ after the morning feeding, the rumen fluid was sampled for the determination of $\mathrm{pH}$ value, $\mathrm{NH}_{3}-\mathrm{N}$ and volatile fatty acids (VFA) concentrations. The $\mathrm{pH}$ value of the ruminal fluid was immediately determined using digital portable $\mathrm{pH}$ meter (WinLab, portable) and samples were immediately frozen at $-20^{\circ} \mathrm{C}$. For $\mathrm{NH}_{3}-\mathrm{N}$ analysis, $20 \mathrm{~mL}$ of the filtered rumen fluid was transferred to tubes and preserved with $20 \mathrm{~mL}$ of a $0.1 \mathrm{~N}$ sulphuric acid solution [23]. For VFA analysis, $20 \mathrm{~mL}$ of the filtered rumen fluid was transferred to second tube and $5 \mathrm{~mL}$ of a $25 \%$ meta-phosphoric acid solution was added to preserve the sample.

\section{Chemical analysis}

Silage and concentrate samples were analyzed for $\mathrm{CP}(\mathrm{N} \times 6.25$; AOAC [24]; method 990.03, using Kjeltec2300 Auto analyzer, Foss Tecator AB, Hoganas, Sweden), NDF (assayed without heat stable amylase and sodium sulphite) and acid detergent fiber (ADF; Van Soest et al [15]), and also buffering capacity for silage samples (BC [25]). Moreover, $\mathrm{CP}, \mathrm{NDF}$, and DM contents were determined for AIA analysis for both feed and fecal samples. Water soluble carbohydrate (WSC [26]) concentration were measured for silages by an anthrone-sulphuric acid procedure using glucose as standard. Aerobic stability was defined as the time needed the silage remained stable before increasing to more than $2^{\circ} \mathrm{C}$ above the ambient temperature and measured in accordance with methodology given by Kleinschmit and Kung [27]. Samples of silage extract for $\mathrm{pH}$ value and $\mathrm{NH}_{3}-\mathrm{N}$ concentration were prepared by blending $50 \mathrm{~g}$ of fresh silage and $450 \mathrm{~mL}$ of doubled distilled water $(\mathrm{w} / \mathrm{v})$ to a homogenized state using a blender for $2 \mathrm{~min}$, then $\mathrm{pH}$ was determined immediately by a digital portable $\mathrm{pH}$ meter (WinLab, portable). A portion of extracts strained through 4 layers of cheesecloth and $5 \mathrm{~mL}$ of fluid samples were acidified with $5 \mathrm{~mL}$ of $0.2 \mathrm{~N} \mathrm{HCL}$, then centrifuged at $3,500 \times \mathrm{g}$ for $10 \mathrm{~min}$, to determine $\mathrm{NH}_{3}-\mathrm{N}$ concentration. The rumen VFA composition was determined by gas chromatography (Chrompack, model CP-9002; Chrompack International BV, Middelburg, the Netherlands) using a 50-m fused-silica column (CP-Wax Chrompack Capillary Column; Varian Inc., Palo Alto, CA, USA), and crotonic acid as the internal standard. Nitrogen was used as carrier gas, and oven initial and final temperatures were $55^{\circ} \mathrm{C}$ and $195^{\circ} \mathrm{C}$, respectively. Detector and injector temperatures were set at $250^{\circ} \mathrm{C}$.

\section{Calcluations}

The UNDF was calculated as 100 - in vitro NDF digestibility (IVNDFD), where IVNDFD was $\% \mathrm{NDF}=\left(1-\left[\mathrm{NDF}_{\text {residual }}{ }^{-}\right.\right.$ $\left.\mathrm{NDF}_{\text {blank }} / \mathrm{NDF}_{\text {sample }}\right) \times 100$, the amount of pdNDF is calculated from the difference of total NDF and UNDF (pdNDF as \% DM $\left.=\left[100-\% \mathrm{uNDF}_{240 \mathrm{~h}}\right] \times \% \mathrm{NDF}_{\text {sample }} ;[28]\right)$. The yield of $3.5 \%$ FCM and energy-corrected milk (ECM) were calculated according to NRC equations [16]:

$$
\begin{aligned}
\mathrm{FCM}= & 0.432 \times \text { milk yield }+16.23 \times \text { fat yield } \\
\mathrm{ECM}= & 12.82 \times \text { fat yield }+7.13 \times \text { protein yield } \\
& +0.323 \times \text { milk yield }
\end{aligned}
$$

Apparent digestibility coefficients (\%) for DM, CP, and NDF were calculated as: $\left(\left[1-\{\mathrm{F} / \mathrm{D}\} \times \mathrm{D}_{\mathrm{m}} / \mathrm{F}_{\mathrm{m}}\right]\right) \times 100$ Where $\mathrm{F}$ $=\%$ nutrient in faeces, $\mathrm{D}=\%$ nutrient in diet, $\mathrm{D}_{\mathrm{m}}=\%$ marker in diet, and $\mathrm{F}_{\mathrm{m}}=\%$ marker in faeces.

\section{Statistical analysis}

In order to assess the differences between non-repeated data including silage composition, blood metabolites, $\mathrm{pH}$ value, rumen fermentation, body temperature and total tract digestibility, they were analyzed using the general linear models procedure of SAS [29]. Statistical model was considered: $Y_{i j}$ $=\mu+T_{i}+\varepsilon_{i j}$, where $Y_{i j}$ is the response for the jth observation of the ith treatment, $\mu$ is the population mean, $T_{i}$ is the ith treatment effect and $\varepsilon_{\mathrm{ij}}$ is the random residual. Data of feed intake, milk production and composition as well as body score, were analyzed using mixed model as repeated measure procedure of SAS (SAS Institute, Cary, NC, USA). Treatment considered as fixed effect. The REML method was used to estimate least 
squares means (LSM), and the Kenward-Roger method was used to calculate denominator degrees of freedom. The variance-covariance error structure was compound symmetry, because it gave minimum akaike information and corrected bayesian information criterions. The statistical model used for analyses was: $Y_{i j}=\mu+T_{i}+A_{j}+\varepsilon_{i j}$, where $Y_{i j}$ was each observation, $\mu$ was the overall mean, $T_{i}$ was the fixed effect of treatment $i$, $\mathrm{A}_{\mathrm{j}}$ was the random effect of cow and $\varepsilon_{\mathrm{ij}}$ was residual error. The interaction between treatment and time was also included in the model, but it was not significant and dropped from the model. Contrasts were tested using the CONTRAST statement of SAS to evaluate the high and low uNDF diets and also the corn silage compared with the WBC silage. Differences among means were tested using the LSMEANS test. The PDIFF option in the LSMEANS statement was used to separate means. Standard errors of means were calculated from the residual mean square in analysis of variance. Significance was declared at $\mathrm{p} \leq 0.05$ and tendencies were explained at $\mathrm{p} \leq 0.10$.

\section{RESULTS}

Silage chemical composition and quality evaluation The type of silage (corn, WBC, and alfalfa), regardless of the additives used, affected the concentrations of $\mathrm{DM}, \mathrm{ADF}$, and WSC, and the buffering capacity ( $\mathrm{mENaOH} / 100 \mathrm{~g} \mathrm{DM} ; \mathrm{BC})$ (Table 3). Accordingly, $\mathrm{BC}$ and $\mathrm{ADF}$ concentration were the highest for the alfalfa silage, intermediate for the WBC silage, and the lowest for the corn silage. The DM and WSC concentrations were the highest for the corn and WBC silages, respectively, while the alfalfa silage had the lowest DM and WSC concentrations. Ammonia-N concentrations and crude protein were increased by supplementation urea to the corn and WBC silages $(\mathrm{p}<0.05)$. Formic acid-treated alfalfa silages had lower $\mathrm{NH}_{3}-\mathrm{N}$ concentration and higher protein content than those of the untreated silages $(\mathrm{p}<0.05)$. Urea improved aerobic stability in the corn and WBC silages. Although the alfalfa silage had higher aerobic stability than those of the corn and WBC silages $(\mathrm{p}<0.05)$, formic acid unaffected aerobic stability ( $p>0.05$ ). The undigested NDF at 30 and $120 \mathrm{~h}$ of incubation was affected by urea in the corn and WBC silages; it was lower than those of the untreated silages $(p<0.05)$. However, formic acid decreased only uNDF at $30 \mathrm{~h}$ incubation. We observed no detectable differences for UNDF at $240 \mathrm{~h}$ across additives and their untreated silages, although it was affected by type of silages and was the highest for the alfalfa, intermediate for the WBC and the lowest for the corn silages.

\section{Feed intake, digestibility and animal body status}

The DMI, final BW, BW changes thorough the trail and means of body condition scores were similar across cows fed high or low uNDF diets and also between two different NDF sources of corn and WBC silages (Table 4). The daily silage $\mathrm{uNDF}_{30 \mathrm{~h}}$ and $\mathrm{uNDF}_{120 \mathrm{~h}}$ intake were lower in the cows fed diets based on urea and formic acid treated silages than those fed the untreated silages $(\mathrm{p}<0.05)$. The daily silage $\mathrm{uNDF}_{240 \mathrm{~h}}$ intake was lower in the $\mathrm{CS}_{\mathrm{U}} \mathrm{AS}$ and $\mathrm{BS}_{\mathrm{U}} \mathrm{AS}$ groups than those of the CSAS and BSAS $(\mathrm{p}<0.05)$, while $\mathrm{uNDF}_{240 \mathrm{~h}}$, unlike $\mathrm{uNDF}_{30 \mathrm{~h}}$ was same in the cows fed the $\mathrm{CSAS}_{\mathrm{F}}$ and $\mathrm{BSAS}_{\mathrm{F}}$ compared with the CSAS and BSAS groups. Additionally, the cows fed diets based on corn silage compared with those received the WBC silage had much lower the daily uNDF intake $(\mathrm{p}<0.05)$. Body surface temperatures were similar among the treatments $(\mathrm{p}>$

Table 3. Chemical composition, pH, aerobic stability, buffering capacity (BC) and in vitro undigested NDF at 30 until $240 \mathrm{~h}$ of untreated and treated with additives of corn, barley and alfalfa silages

\begin{tabular}{|c|c|c|c|c|c|c|c|c|}
\hline \multirow{2}{*}{ Parameters } & \multicolumn{6}{|c|}{ Treatments $^{1)}$} & \multirow{2}{*}{ SEM } & \multirow{2}{*}{$p$-value } \\
\hline & $\mathrm{CSC}$ & CSU & BSC & BSU & ASC & ASF & & \\
\hline DM $(\mathrm{g} / \mathrm{kg})$ & $31.37^{\mathrm{a}}$ & $30.02^{a}$ & $27^{b}$ & $26.71^{b}$ & $24.6^{c}$ & $24.74^{c}$ & 0.73 & $<0.001$ \\
\hline $\mathrm{pH}$ & $3.68^{c}$ & $4.10^{b}$ & $4.51^{\mathrm{ab}}$ & $4.71^{\mathrm{a}}$ & $4.83^{\mathrm{a}}$ & $4.11^{b c}$ & 0.19 & 0.001 \\
\hline $\mathrm{NH}_{3}-\mathrm{N}(\mathrm{mg} / \mathrm{dL})$ & $1.86^{\mathrm{e}}$ & $3.70^{b}$ & $2.08^{\mathrm{de}}$ & $3.94^{\mathrm{a}}$ & $2.27^{\mathrm{cd}}$ & $2.35^{\mathrm{e}}$ & 0.06 & $<0.001$ \\
\hline $\mathrm{CP}(\mathrm{g} / \mathrm{kg})$ & $82.22^{f}$ & $101.76^{e}$ & $113.61^{d}$ & $137.11^{c}$ & $172.72^{b}$ & $177.73^{\mathrm{a}}$ & 0.75 & $<0.001$ \\
\hline $\operatorname{NDF}(\mathrm{g} / \mathrm{kg})$ & $558.78^{\mathrm{a}}$ & $518.57^{d}$ & $541.43^{b}$ & $529.58^{c}$ & $562.42^{\mathrm{a}}$ & $546.56^{b}$ & 3.29 & $<0.001$ \\
\hline$A D F(g / k g)$ & $347.83^{c}$ & $343.87^{c}$ & $365.50^{b}$ & $373.73^{b}$ & $397.26^{\mathrm{a}}$ & $401.22^{\mathrm{a}}$ & 2.85 & $<0.001$ \\
\hline WSC $(\mathrm{g} / \mathrm{kg})$ & $18.64^{b}$ & $17.65^{b}$ & $22.40^{\mathrm{a}}$ & $22.68^{\mathrm{a}}$ & $8.60^{c}$ & $8.49^{c}$ & 0.44 & $<0.001$ \\
\hline $\mathrm{BC}(\mathrm{mE} \mathrm{NaOH} / 100 \mathrm{~g})$ & $74.17^{c}$ & $74.28^{c}$ & $78.56^{b}$ & $78.33^{b}$ & $118.80^{\mathrm{a}}$ & $118.66^{\mathrm{a}}$ & 0.91 & $<0.001$ \\
\hline AS (hours) & $33.50^{c}$ & $44.66^{b}$ & $21^{d}$ & $28^{c}$ & $70.66^{\mathrm{a}}$ & $74.66^{\mathrm{a}}$ & 2.03 & $<0.001$ \\
\hline $\mathrm{uNDF}_{30 \mathrm{~h}}(\%$ of NDF) & $51.60^{e}$ & $48.80^{f}$ & $59.21^{c}$ & $55.67^{d}$ & $67.73^{\mathrm{a}}$ & $64.42^{b}$ & 0.77 & $<0.001$ \\
\hline $\mathrm{uNDF}_{120 \mathrm{~h}}(\%$ of NDF) & $42.64^{d}$ & $41.51^{e}$ & $52.19^{b}$ & $51.09^{c}$ & $54.67^{\mathrm{a}}$ & $53.89^{\mathrm{a}}$ & 0.31 & $<0.001$ \\
\hline $\mathrm{uNDF}_{240 \mathrm{~h}}(\%$ of NDF) & $31.19^{c}$ & $29.49^{c}$ & $39.42^{b}$ & $36.76^{b}$ & $46.21^{\mathrm{a}}$ & $45.33^{\mathrm{a}}$ & 0.89 & $<0.001$ \\
\hline
\end{tabular}

NDF, neutral detergent fiber; SEM, standard error of the mean; DM, dry matter; CP, crude protein; ADF, acid detergent fiber; WSC, whole barley crop; AS, alfalfa silage; uNDF, undigested neutral detergent fiber.

1) CSC, untreated corn silage; CSU, corn silage treated with urea; BSC, untreated barley silage; BSU, barley silage treated with urea; ASC, untreated alfalfa silage; ASF, alfalfa silage treated with formic acid.

a-f Least squares means within a row with different superscripts differ significantly $(p<0.05)$. 
Table 4. Feed intake, silage uNDF intake at 30, 120, and 240 h, BW, BCS, body surface temperature, feed efficiency and total tract nutrient digestibility of cows fed diets based on high or low UNDF with silage additives

\begin{tabular}{|c|c|c|c|c|c|c|c|c|c|c|}
\hline \multirow{4}{*}{ Parameters } & \multicolumn{6}{|c|}{ Treatments } & \multirow{4}{*}{ SEM } & \multirow{4}{*}{$\mathrm{p}$-value } & \multicolumn{2}{|c|}{ Contrasts } \\
\hline & \multicolumn{3}{|c|}{ Corn silage } & \multicolumn{3}{|c|}{ WBC silage } & & & \multirow{3}{*}{$\begin{array}{l}\text { High uNDF } \\
\text { vs low uNDF }\end{array}$} & \multirow{3}{*}{$\begin{array}{c}\text { Corn silage } \\
\text { vs WBC } \\
\text { silage }\end{array}$} \\
\hline & \multirow{2}{*}{$\frac{\text { High uNDF }}{\text { CSAS }^{1)}}$} & \multicolumn{2}{|c|}{ Low uNDF } & \multirow{2}{*}{$\frac{\text { High uNDF }}{\text { BSAS }^{1)}}$} & \multicolumn{2}{|c|}{ Low uNDF } & & & & \\
\hline & & $\mathrm{CS}_{\mathrm{U}} \mathrm{AS}^{1)}$ & CSAS $_{\mathrm{F}}{ }^{1)}$ & & $\mathrm{BS}_{\mathrm{U}} \mathrm{AS^{1) }}$ & BSAS $_{\mathrm{F}}{ }^{1)}$ & & & & \\
\hline $\mathrm{DMI}(\mathrm{kg} / \mathrm{d})$ & 23.13 & 22.98 & 23.26 & 23.05 & 23.18 & 23.24 & 0.23 & 0.35 & 0.44 & 0.40 \\
\hline Silage $\mathrm{NDF}_{30 \mathrm{~h}}$ intake $(\mathrm{kg} / \mathrm{d})$ & $2.59^{b}$ & $2.32^{c}$ & $2.40^{c}$ & $2.82^{\mathrm{a}}$ & $2.51^{b}$ & $2.54^{b}$ & 0.05 & 0.04 & 0.03 & 0.04 \\
\hline Silage uNDF $_{120 h}$ intake $(\mathrm{kg} / \mathrm{d})$ & $2.09^{b}$ & $1.72^{c}$ & $1.80^{c}$ & $2.31^{\mathrm{a}}$ & $2.16^{b}$ & $2.19^{b}$ & 0.04 & 0.03 & 0.05 & 0.03 \\
\hline Silage $\mathrm{uNDF}_{240 \mathrm{~h}}$ intake $(\mathrm{kg} / \mathrm{d})$ & $1.56^{c}$ & $1.31^{d}$ & $1.49^{\text {cd }}$ & $1.99^{\mathrm{a}}$ & $1.69^{b}$ & $1.89^{\mathrm{a}}$ & 0.04 & 0.04 & 0.03 & 0.01 \\
\hline BW $(k g)$ & 600 & 597.16 & 594.16 & 592.83 & 593.80 & 602.66 & 12.58 & 0.87 & 0.86 & 0.57 \\
\hline BW gain/period $(\mathrm{kg} / \mathrm{d})$ & 0.32 & 0.28 & 0.29 & 0.27 & 0.29 & 0.46 & 0.10 & 0.59 & 0.57 & 0.33 \\
\hline BCS & 3.5 & 3.1 & 3.3 & 3.3 & 3.3 & 3.5 & 0.06 & 0.53 & 0.50 & 0.40 \\
\hline Body temperature $\left({ }^{\circ} \mathrm{C}\right)$ & 16.62 & 21.98 & 19.01 & 19.48 & 18.80 & 18.97 & 3.93 & 0.96 & 0.76 & 0.97 \\
\hline Feed efficiency (milk yield/DMI) & $1.27^{\mathrm{b}}$ & $1.35^{\mathrm{a}}$ & $1.28^{b}$ & $1.22^{b}$ & $1.24^{b}$ & $1.24^{b}$ & 0.04 & 0.04 & 0.38 & 0.21 \\
\hline DM digestibility (\%) & 62.29 & 68.20 & 63.90 & 64.20 & 65.77 & 69.44 & 2.26 & 0.64 & 0.53 & 0.71 \\
\hline CP digestibility (\%) & 68.29 & 70.44 & 71.39 & 66.88 & 71.10 & 60.28 & 3.33 & 0.82 & 0.51 & 0.79 \\
\hline NDF digestibility (\%) & $45.26^{b}$ & $47.80^{\mathrm{a}}$ & $47.71^{\mathrm{a}}$ & $46.08^{b}$ & $48.09^{a}$ & $47.88^{\mathrm{a}}$ & 1.18 & 0.05 & 0.03 & 0.44 \\
\hline
\end{tabular}

uNDF, undigested neutral detergent fiber; BW, body weight; BCS, body condition score; WBC, whole barley crop; SEM, standard error of the mean; DMI, dry matter intake; DM, dry matter; $C P$, crude protein; NDF, neutral detergent fiber.

1) CSAS, untreated corn and alfalfa silages; $C S_{U} A S$, urea-treated corn silage+untreated alfalfa silage; $C_{F} S_{F}$ untreated corn silage+formic acid-treated alfalfa silage; BSAS, untreated barley and alfalfa silages; $B S_{U} A S$, urea-treated barley silage+untreated alfalfa silage; $B_{S A S}$ untreated barley silage+formic acid-treated alfalfa silage.

${ }^{a-c}$ Least squares means within a row with different superscripts differ significantly $(p<0.05)$.

0.05). Feed efficiency was the highest in the $\mathrm{CS}_{U} \mathrm{AS}$ than those of the other treatments $(\mathrm{p}<0.05)$. The apparent total tract digestibility of NDF (NDFD) was higher in the cows fed low uNDF silages than those fed the high uNDF, untreated silages $(\mathrm{p}<0.05)$. However, the apparent total tract digestibility of dry matter and crude protein were not affected among the cows fed high or low uNDF ( $p>0.05)$. Likewise, we observed no significant differences between diets based on the corn and WBC silages for total tract digestibility of the nutrients.

\section{Milk yield and composition}

The data related to milk yield and milk composition as a result of the different uNDF rations are presented in Table 5 . Decreasing uNDF due to the inclusion of urea to the corn

Table 5. Milk yield, FCM, ECM and milk composition (percentage or kg/d) of cows fed diets based on high or low uNDF with silage additives

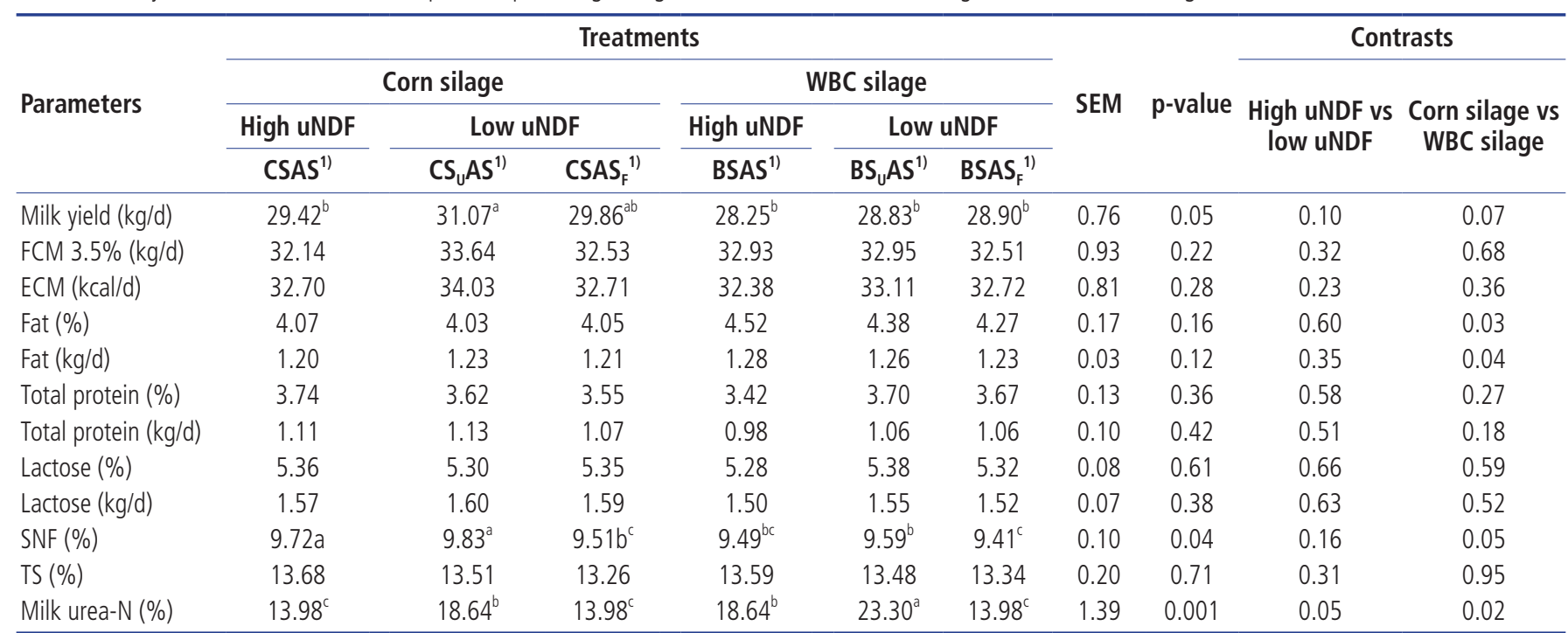

FCM, fat-corrected milk; ECM, energy-corrected milk; UNDF, undigested neutral detergent fiber; WBC, whole barley crop; SEM, standard error of the mean; SNF, solid non-fat; TS, total solids.

1) CSAS, untreated corn and alfalfa silages; $C S_{U} A S$, urea-treated corn silage+untreated alfalfa silage; $C S A S_{F}$ untreated corn silage+formic acid-treated alfalfa silage; BSAS, untreated barley and alfalfa silages; $B S_{U} A S$, urea-treated barley silage+untreated alfalfa silage; $B_{S A S_{F}}$ untreated barley silage+formic acid-treated alfalfa silage.

${ }^{a-c}$ Least squares means within a row with different superscripts differ significantly $(p<0.05)$. 
silage $\left(\mathrm{CS}_{\mathrm{U}} \mathrm{AS}\right)$ increased milk yield, while the addition of formic acid to the alfalfa $\left(\mathrm{CSAS}_{\mathrm{F}}\right.$ and $\left.\mathrm{BSAS}_{\mathrm{F}}\right)$ did not change milk production. Compared to diets based on the WBC silage, the corn silage tended to increase $(\mathrm{p}=0.07)$ milk production. When the intake of silage NDF and UNDF increased, the milk production decreased and was minimum when the cows were fed diets based on silages with 4.15 and $1.99 \mathrm{~kg}$ of NDF and $\mathrm{uNDF}$, respectively (Figure 1 ; adj $\mathrm{R}^{2}=0.79$ ). Fat-corrected milk and energy-corrected milk yields were unaffected by the uNDF levels or the source of NDF supplied in the diets ( $p>$ 0.05). Although reducing uNDF through the inclusion of additives did not affect milk fat yield and percentage, the change of NDF source from the corn silage to the WBC silage caused a significant increase in fat yield and fat percentage $(\mathrm{p}<0.05)$. Milk urea-N was higher in the cows fed $\mathrm{CS}_{\mathrm{U}} \mathrm{AS}$ and $\mathrm{BS}_{\mathrm{U}} \mathrm{AS}$ than those fed CSAS, CSAS $\mathrm{F}$, BSAS and $\mathrm{BSAS}_{\mathrm{F}}(\mathrm{p}<0.05)$. Replacing the source of NDF, as a result of changing from the corn silage to the WBC silage, significantly increased milk urea-N ( $\mathrm{p}<0.05)$. Solid non-fat milk (SNF) was the highest in the cows fed the $\mathrm{CS}_{\mathrm{U}} \mathrm{AS}$ and the lowest in those fed the BSAS $\mathrm{F}$ The substitution of corn silage with WBC silage decreased the SNF content. The effects of the different uNDF levels or NDF sources were not observed on protein, lactose, and total solid across the treatments $(\mathrm{p}>0.05)$.

\section{Ruminal fermentation characteristics}

Ruminal propionate, acetate and butyrate concentrations as well as acetate to propionate ratio were not affected by uNDF levels in the cows fed the experimental diets $(p>0.05$; Table 6). The type of physical NDF included in the experimental ration did not change the VFA concentrations in the cows fed diets based on the corn silage rather than those fed the WBC silage. Moreover, we observed no significant differences for ruminal $\mathrm{pH}$ value across the treatments with various $\mathrm{UNDF}$ ( $p>0.05$ ). Reducing uNDF in the $\mathrm{CS}_{\mathrm{U}} \mathrm{AS}$ and $\mathrm{BS}_{\mathrm{U}} \mathrm{AS}$ caused higher $\mathrm{NH}_{3}-\mathrm{N}$ concentration in the rumen. Nevertheless, the

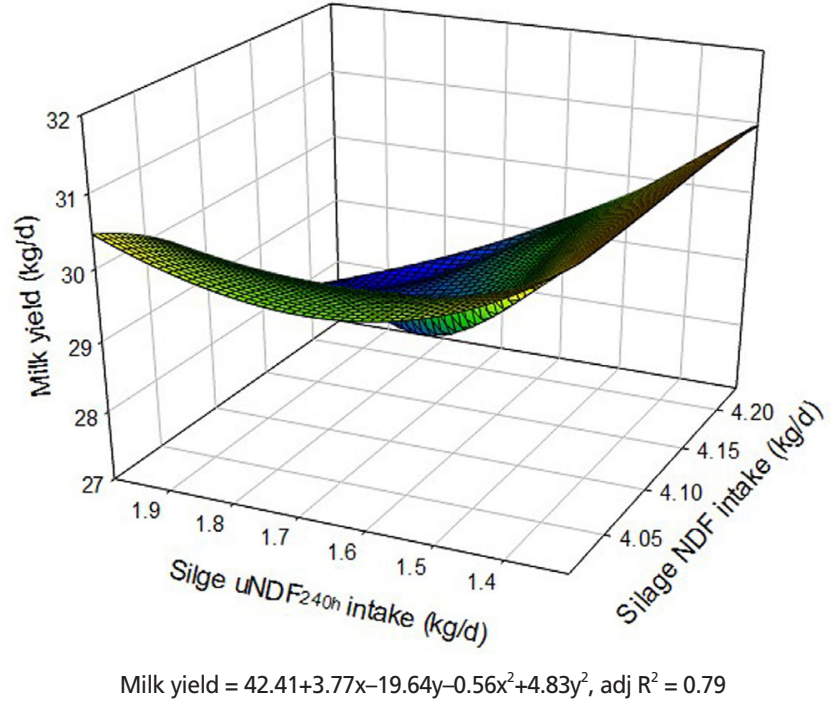

Figure 1. 3D surface responses to silage NDF and $\mathrm{UNDF}_{240 \mathrm{~h}}$ intake on milk yield of Holstein dairy cows. NDF, neutral detergent fiber; UNDF, undigested NDF.

$\mathrm{CSAS}_{\mathrm{F}}$ had lower $\mathrm{NH}_{3}-\mathrm{N}$ concentration than those fed the CSAS $(p<0.05)$. Furthermore, the cows fed diets based on corn silage experienced lower $\mathrm{NH}_{3}-\mathrm{N}$ concentration than those fed the WBC silage $(\mathrm{p}<0.05)$.

\section{Eating and ruminating}

The results of eating, ruminating and water drinking activities are reported in Table 7 . There were no significant differences in eating time $(\mathrm{min} / \mathrm{d})$ and eating time adjusted for $\mathrm{DM}$ and $\mathrm{NDF}$ intake ( $\mathrm{min} / \mathrm{kg}$ of DM and NDF, respectively) among the diets based on high or low uNDF content and also, for sources of NDF supply through the corn or WBC silages ( $\mathrm{p}>$ 0.05). Although rumination time was unaffected by reducing uNDF via inclusion of urea or formic acid to the corn, WBC and alfalfa silages, the cows fed diets based on WBC silage experienced greater ruminating time than those fed the corn

Table 6. Ruminal pH value, $\mathrm{NH}_{3}-\mathrm{N}$ and VFA concentrations of cows fed diets based on high or low uNDF with silage additives

\begin{tabular}{|c|c|c|c|c|c|c|c|c|c|c|}
\hline \multirow{4}{*}{ Parameters } & \multicolumn{6}{|c|}{ Treatments } & \multirow{4}{*}{ SEM } & \multirow{4}{*}{$\mathrm{p}$-value } & \multicolumn{2}{|c|}{ Contrasts } \\
\hline & \multicolumn{3}{|c|}{ Corn silage } & \multicolumn{3}{|c|}{ WBC silage } & & & \multirow{3}{*}{$\begin{array}{l}\text { High uNDF vs } \\
\text { low uNDF }\end{array}$} & \multirow{3}{*}{$\begin{array}{l}\text { Corn silage vs } \\
\text { WBC silage }\end{array}$} \\
\hline & \multirow{2}{*}{$\begin{array}{c}\text { High uNDF } \\
\text { CSAS }^{1)}\end{array}$} & \multicolumn{2}{|c|}{ Low uNDF } & \multirow{2}{*}{$\frac{\text { High uNDF }}{\text { BSAS }^{1)}}$} & \multicolumn{2}{|c|}{ Low uNDF } & & & & \\
\hline & & $\mathrm{CS}_{\mathrm{U}} A \mathrm{~S}^{1)}$ & CSAS $_{\mathrm{F}}{ }^{1)}$ & & $\mathrm{BS}_{\mathrm{U}} A \mathrm{~S}^{1)}$ & BSAS $_{\mathrm{F}}{ }^{1)}$ & & & & \\
\hline $\mathrm{pH}$ & 6.27 & 6.71 & 6.49 & 6.47 & 6.54 & 6.53 & 0.31 & 0.97 & 0.66 & 0.98 \\
\hline $\mathrm{NH}_{3}-\mathrm{N}(\mathrm{mg} / \mathrm{dL})$ & $13.51^{d}$ & $14.13^{b}$ & $13.30^{c}$ & $14.23^{b}$ & $14.67^{\mathrm{a}}$ & $14.04^{b}$ & 0.06 & $<0.001$ & $<0.001$ & $<0.001$ \\
\hline Acetate (mM) & 52.73 & 43.88 & 46.65 & 62.01 & 54.94 & 40.73 & 6.78 & 0.32 & 0.34 & 0.48 \\
\hline Propionate (mM) & 27.96 & 37.80 & 27.50 & 28.84 & 25.57 & 30.29 & 4.95 & 0.41 & 0.52 & 0.26 \\
\hline Butyrate (mM) & 6.88 & 5.98 & 6.42 & 5.41 & 6.64 & 6.29 & 1.64 & 0.58 & 0.57 & 0.48 \\
\hline Acetate:propionate & 1.89 & 1.17 & 1.69 & 2.15 & 2.14 & 1.34 & 0.51 & 0.62 & 0.55 & 0.31 \\
\hline
\end{tabular}

VFA, volatile fatty acids; UNDF, undigested neutral detergent fiber; WBC, whole barley crop; SEM, standard error of the mean.

1) CSAS, untreated corn and alfalfa silages; $C S_{U} A S$, urea-treated corn silage+untreated alfalfa silage; $C_{S A S}$, untreated corn silage+formic acid-treated alfalfa silage; BSAS, untreated barley and alfalfa silages; $B S_{U} A S$, urea-treated barley silage+untreated alfalfa silage; $B_{S A S_{F}}$ untreated barley silage+formic acid-treated alfalfa silage.

${ }^{a-c}$ Least squares means within a row with different superscripts differ significantly $(p<0.05)$. 
Table 7. Eating, ruminating and water drinking activities of cows fed diets based on high or low uNDF with silage additives

\begin{tabular}{|c|c|c|c|c|c|c|c|c|c|c|}
\hline \multirow{3}{*}{ Parameters } & \multicolumn{6}{|c|}{ Treatments } & \multirow{3}{*}{ SEM } & \multirow{3}{*}{$p$-value } & \multicolumn{2}{|c|}{ Contrasts } \\
\hline & \multicolumn{3}{|c|}{ Corn silage } & \multicolumn{3}{|c|}{ WBC silage } & & & \multirow{2}{*}{$\begin{array}{l}\text { High uNDF vs } \\
\text { low uNDF }\end{array}$} & \multirow{2}{*}{$\begin{array}{l}\text { Corn silage vs } \\
\text { WBC silage }\end{array}$} \\
\hline & $\frac{\text { High uNDF }}{\text { CSAS }^{1)}}$ & \multicolumn{2}{|c|}{ Low uNDF } & $\frac{\text { High uNDF }}{\text { BSAS }^{1)}}$ & \multicolumn{2}{|c|}{ Low uNDF } & & & & \\
\hline Eating (min) & 406.66 & 426.66 & 426.66 & 393.33 & 406.66 & 405.33 & 17.63 & 0.71 & 0.51 & 0.21 \\
\hline Eating DM (min) & 5.80 & 6.35 & 6.29 & 5.34 & 5.69 & 5.50 & 0.55 & 0.74 & 0.64 & 0.20 \\
\hline Rumination DM (min) & $7.93^{b}$ & $7.89 \mathrm{~b}$ & $7.40^{b}$ & $9.06^{\mathrm{a}}$ & $8.67^{\mathrm{a}}$ & $8.70^{\mathrm{a}}$ & 0.29 & 0.04 & 0.52 & 0.002 \\
\hline Rumination NDF (min) & $25.40^{b}$ & $25.30^{b}$ & $24.82^{b}$ & $28.96^{\mathrm{a}}$ & $27.71^{\mathrm{a}}$ & $27.80^{\mathrm{a}}$ & 1.07 & 0.05 & 0.50 & 0.003 \\
\hline Water drinking (min) & 36.66 & 40.00 & 43.33 & 46.66 & 43.33 & 46.66 & 5.09 & 0.71 & 0.68 & 0.20 \\
\hline Water DM (min) & 1.01 & 1.12 & 1.18 & 1.29 & 1.20 & 1.37 & 0.13 & 0.77 & 0.64 & 0.10 \\
\hline Water NDF (min) & 3.23 & 3.61 & 3.77 & 4.14 & 3.83 & 4.40 & 0.43 & 0.60 & 0.65 & 0.10 \\
\hline
\end{tabular}

UNDF, undigested neutral detergent fiber; WBC, whole barley crop; SEM, standard error of the mean; DM, dry matter.

1) $C S A S$, untreated corn and alfalfa silages; $C S_{U} A S$, urea-treated corn silage+untreated alfalfa silage; $C S A S_{F}$ untreated corn silage+formic acid-treated alfalfa silage; $B S A S$, untreated barley and alfalfa silages; $B S_{U} A S$, urea-treated barley silage+untreated alfalfa silage; $B_{S A S}$ untreated barley silage+formic acid-treated alfalfa silage.

${ }^{a-b}$ Least squares means within a row with different superscripts differ significantly $(p<0.05)$.

silage, as different UNDF content and physical NDF supplied source $(\mathrm{p}<0.05)$. Longer ruminating time associated with substitution of the corn silage with the WBC silage was not corresponded to eating time. Hence, total chewing activity (eating+ruminating) was not affected by the type of silages $(\mathrm{p}>0.05)$. There was a strong relationship between silage NDF and uNDF intake with rumination time and the highest rumination activity was observed when the cows were fed diets based on silages with $4.1 \mathrm{~kg} \mathrm{NDF}$ and $1.99 \mathrm{~kg}$ uNDF (Figure $\left.2, \operatorname{adj} R^{2}=90\right)$. There were no detectable differences for water

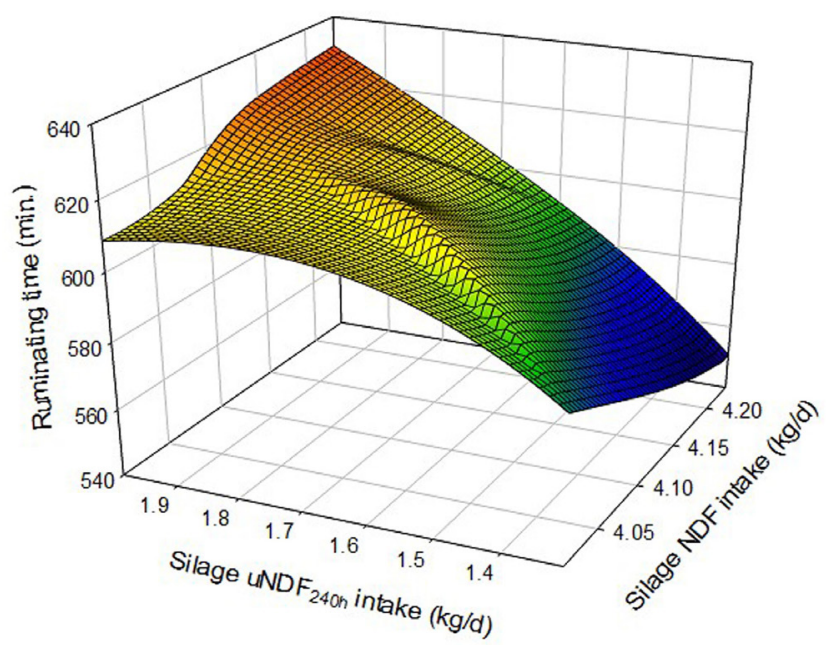

Rumination time $=836.71-88.99 x+79.89 y$, adj $R^{2}=0.90$

Figure 2. 3D surface responses to silage NDF and $\mathrm{UNDF}_{240 \mathrm{~h}}$ intake on ruminating time of Holstein dairy cows. NDF, neutral detergent fiber; UNDF, undigested NDF. drinking time ( $\mathrm{min} / \mathrm{d}$ ) among cows fed different levels of uNDF ( $p>0.05$ ). Nevertheless, the cows fed diets based on the WBC silage tended to have longer times of water drinking adjusted for DM and NDF ( $\mathrm{p}=0.10)$ compared with those fed the corn silage.

\section{Blood metabolites}

Decreasing uNDF due to the inclusion of urea and formic acid to the silages did not affect the concentrations of glucose, triglyceride, cholesterol, and AST (Table 8). However, blood urea- $\mathrm{N}$ and alanine aminotransferase concentrations increased in the cows fed low uNDF diet $\left(\mathrm{CS}_{\mathrm{U}} \mathrm{AS}\right.$ and $\left.\mathrm{BS}_{\mathrm{U}} \mathrm{AS} ; \mathrm{p}<0.10\right)$. The substitution of WBC silages with corn silage increased blood urea- $\mathrm{N}(\mathrm{p}=0.03)$ as well as alanine aminotransferase concentrations $(p=0.09)$. Nonetheless, no significant differences for blood concentrations of glucose, triglyceride and AST for two different source of uNDF (corn vs WBC) were observed $(\mathrm{p}>0.05)$.

\section{DISCUSSION}

\section{Silage fermentation and animal performance}

In the present study, we evaluate the effect of various organic additives, which are mostly used in commercial dairy farms, on the pattern of the corn, WBC and alfalfa silages fermentation. In addition, we hypothesis whether the additives may alter the nature of NDF during ensiling. It has previously proposed that the silage additives can affect nutritional value and fermentation characteristics of the ensiled forages $[30,9]$. Therefore, we speculate that the treated silages lead to changes in 
Table 8. Blood metabolites concentration of cows fed diets based on high or low uNDF with silage additives

\begin{tabular}{|c|c|c|c|c|c|c|c|c|c|c|}
\hline \multirow{4}{*}{ Parameters } & \multicolumn{6}{|c|}{ Treatments } & \multirow{4}{*}{ SEM } & \multirow{4}{*}{$p$-value } & \multicolumn{2}{|c|}{ Contrasts } \\
\hline & \multicolumn{3}{|c|}{ Corn silage } & \multicolumn{3}{|c|}{ WBC silage } & & & \multirow{3}{*}{$\begin{array}{l}\text { High uNDF vs } \\
\text { low uNDF }\end{array}$} & \multirow{3}{*}{$\begin{array}{l}\text { Corn silage } \\
\text { vs WBC silage }\end{array}$} \\
\hline & \multirow{2}{*}{$\begin{array}{c}\text { High uNDF } \\
\text { CSAS }^{1)}\end{array}$} & \multicolumn{2}{|c|}{ Low uNDF } & \multirow{2}{*}{$\frac{\text { High uNDF }}{\text { BSAS }^{1)}}$} & \multicolumn{2}{|c|}{ Low uNDF } & & & & \\
\hline & & $\mathrm{CS}_{\mathrm{U}} A \mathrm{~S}^{1)}$ & $\mathrm{CSAS}_{\mathrm{F}}{ }^{1)}$ & & $\mathrm{BS}_{\mathrm{U}} \mathrm{AS}^{1)}$ & BSAS $_{\mathrm{F}}{ }^{1)}$ & & & & \\
\hline $\mathrm{TG}(\mathrm{mg} / \mathrm{dL})$ & 13.28 & 21.98 & 19.01 & 19.48 & 18.80 & 15.33 & 4.87 & 0.69 & 0.53 & 0.52 \\
\hline $\mathrm{CHL}(\mathrm{mg} / \mathrm{dL})$ & 277.53 & 283.68 & 304.78 & 289.68 & 282.75 & 249.30 & 18.19 & 0.27 & 0.77 & 0.15 \\
\hline Urea-N (mg/dL) & $15.73^{c}$ & $18.67^{a b}$ & $15.60^{c}$ & $17.23^{b}$ & $19.44^{\mathrm{a}}$ & $16.06^{\mathrm{bc}}$ & 1.10 & 0.03 & 0.05 & 0.03 \\
\hline ALT (mg/dL) & 20.13 & 24.38 & 22.76 & 23.83 & 27.73 & 21.53 & 1.96 & 0.28 & 0.06 & 0.09 \\
\hline AST (mg/dL) & 55.59 & 68.42 & 64.77 & 60.60 & 59.22 & 56.37 & 8.92 & 0.89 & 0.65 & 0.85 \\
\hline Glucose (mg/dL) & 56.03 & 60.28 & 53.15 & 55.10 & 53.28 & 58.60 & 2.10 & 0.32 & 0.22 & 0.21 \\
\hline
\end{tabular}

uNDF, undigested neutral detergent fiber; WBC, whole barley crop; SEM, standard error of the mean; TG, triglycerides; CHL, cholesterol; ALT, alanine aminotransferase; AST, apartate aminotransferase.

1) CSAS, untreated corn and alfalfa silages; $C S_{U} A S$, urea-treated corn silage+untreated alfalfa silage; $C_{\text {S }} S_{F}$ untreated corn silage+formic acid-treated alfalfa silage; BSAS, untreated barley and alfalfa silages; $B S_{U} A S$, urea-treated barley silage+untreated alfalfa silage; $\mathrm{BSAS}_{\mathrm{F}}$ untreated barley silage+formic acid-treated alfalfa silage.

${ }^{a-c}$ Least squares means within a row with different superscripts differ significantly $(p<0.05)$.

uNDF. Therefore, the treated silages in dairy diets may impact the feed intake, nutrient digestibility, chewing activity, milk yield, and milk composition of lactating Holstein dairy cows.

Throughout the experiment, the urea-treated corn and WBC silages had higher $\mathrm{CP}$ and $\mathrm{NH}_{3}-\mathrm{N}$ concentrations and higher $\mathrm{pH}$ value as well as aerobic stability. However, NDF, $\mathrm{uNDF}$ at 30 and $120 \mathrm{~h}$ decreased by applying urea to the corn and WBC silages compared with the untreated silages. These findings do confirm previous findings which indicate that urea addition canimprove aerobic stability during feeding [31] and increase $\mathrm{pH}$ and ammonia- $\mathrm{N}$ concentration [32]. Urea is transformed into ammonia during ensiling. The antimitotic effect of ammonia decreased fungal growth because of the alkaline environment, so urea treated silages had higher aerobic stability [9]. The higher $\mathrm{CP}$ and lower ammonia- $\mathrm{N}$ concentration in the formic acid-treated silages were expected because acids cause a reduction in protein degradation. These results are in line with Jaakkola et al [10] who state that the addition of formic acid to silages may increase protein content and reduce ammonia- $\mathrm{N}$ concentration. The higher $\mathrm{pH}$ in the $\mathrm{WBC}$ and alfalfa silages compared with the corn may be due to their higher buffering capacity (BC), as the higher $\mathrm{CP}$ content of the alfalfa and WBC forages would increase the $\mathrm{BC}$ [8]. Greater WSC concentration in the WBC silage than the corn silage is in agreement with Addah et al [33] who noted that WSC concentration of whole barley forage ensiled was 5 times higher than those of corn.

In the present study, six diets, with the treated and untreated silages, were used. The diets were assigned by different types of silages and UNDF concentrations (low vs high). The results obtained from the lactating Holstein dairy cows demonstrated that DMI was unaffected by the daily silage uNDF intake. This suggests that ruminal pdNDF rate of digestion may drive DMI rather than uNDF. In the study of Grant and Cotanch [34], who used diets based on high or low forage (conventional vs brown midrib corn silage) with different fiber digestibility and uNDF, it was reported that the filling effect of the diet could be related to the amount and rate of degradation of pdNDF fraction rather than uNDF. The lack of impact of replacing the corn silage with the WBC silage in the cows' diet on DMI was not expected. Indeed, because the amount of UNDF at $30 \mathrm{~h}, 120 \mathrm{~h}$, and $240 \mathrm{~h}$ was higher in the WBC silage than that of the corn silage (Table 3), we expected a reduction in DMI as a result of feeding the WBC silage as compared to the corn silage. There was no significant difference among the dietary treatments for body surface temperature; results are expected because of lack of differences in acetate and acetate: propionate ratio (Table 6). A difference in body temperature may reflect a change in the VFA concentration. When acetate in the rumen increased, an increment body temperature occurred due to the heat of fermentation associated with acetate production [35].

In the present study, unlike DMI, the milk yield was improved by reducing the daily uNDF intake due to the inclusion of urea in the corn silage. These findings do confirm the research of Huber and Thomas [36], who reported the incorporation of urea into dairy cattle rations promotes milk production. However, distinct from their experiment, our rations were iso-nitrogenouse while differences for crude protein content among their dietary experiment affected DMI and consequently, milk yield. Furthermore, in our study, the increase in the milk yield of cows fed the $\mathrm{CA}_{U} \mathrm{AS}$ might be due to the reduction of uNDF via urea during silage fermentation. During ensiling, the partial hydrolase of NDF with additives were occurred (Table 3), having an impact on total tract NDF digestibility (Table 4). Therefore, this pre-hydrolase in silages caused to alter readily NDF digestion in the rumen by in- 
creasing surface area available for microbial attack, resulting in a more rapid rate of ruminal fermentation and increased milk yield. Another reason behind the increased milk yield in cows fed the $\mathrm{CS}_{\mathrm{U}} \mathrm{AS}$ than those which take the CSAS might be due to higher silage $\mathrm{pH}$ with the inclusion of urea, followed by its buffering effects on fiber digestibility [7] (Table 3). Likewise, Shaver et al [37] reported that the silage $\mathrm{pH}$ is a factor that affects voluntary feed intake and organic matter intake increased when corn silage $\mathrm{pH}$ is elevated. The silage types (WBC vs corn) affected the milk yield. The milk production was higher in cows fed diets based on the corn silage than those fed the WBS (30.11 vs $28.66 \mathrm{~kg} / \mathrm{d} / \mathrm{head}$ ). In accordance with our results, previous works report a greater milk yield in cows fed corn silage as opposed to cows fed barley silage [38]. However, a few recent studies concluded with a similar effect of diets based on corn or barley silages on milk yield [39]. Decreasing silage NDF and uNDF intake caused an increase in the milk yield and the maximum milk yield was allocated to the cows fed diet based on silages containing 4.0 and $1.3 \mathrm{~kg} / \mathrm{d}$ of NDF and $\mathrm{uNDF}_{240 \mathrm{~h}}$, respectively (Figure 1). These measurements were $0.7 \%$ and $0.22 \%$ of BW for NDF and $\mathrm{uNDF}_{240 \mathrm{~h}}$, respectively. Mertens [40] reported that maximum NDF intake was $1.47 \% \mathrm{BW}$ and forage NDF intake was $1.05 \% \mathrm{BW}$. He also noted that the range of undigested NDF $\left(\mathrm{uNDF}_{240 \mathrm{~h}}\right.$ ) should not be more than $0.30 \%$ to $0.48 \% \mathrm{BW}$ [40]. Increased milk fat yield and fat percentage with changing NDF source from the corn silage to the WBC silage (1.21 and 4.05 vs 1.27 and $4.39 \mathrm{~kg} / \mathrm{d} / \mathrm{head}$, respectively) suggests a longer chewing time for cows fed the WBC silages because of physical properties of fiber and the highest UNDF content. The greater milk urea-N in the cows fed diets based on WBC silage than those fed corn silage (18.64 vs $15.53, \mathrm{~kg} / \mathrm{d} / \mathrm{head}$ ) were majority attributable to the fact that cows fed the WBC silage had higher $\mathrm{NH}_{3}-\mathrm{N}$ concentration in the rumen, which likely reflect to nitrogen construction and utilization between the corn and WBC silages. Another possibility could be that corn silage provides more energy for rumen microbes since it has low uNDF at 30, 120, and $240 \mathrm{~h}$ incubation (Table 3).

The similar $\mathrm{pH}$, VFA concentration, and acetate: propionate ratio between low and high UNDF diets and the source of silage is partly attributable to the fact that the DMI across the treatments was the same (Table 6). Decreasing the $\mathrm{pH}$ and increasing the VFA concentration may decrease DMI [41], but this was not observed in our study. One possible explanation for having same $\mathrm{pH}$ value might be traced to the fact that in our study, the rations contained higher forage and, consequently, the rumen environment was favorable among treatments. The lower rumen $\mathrm{NH}_{3}-\mathrm{N}$ concentration in the diet of cows fed on meals that contained $\mathrm{CSAS}_{\mathrm{F}}$ and $\mathrm{BSAS}_{\mathrm{F}}$ in comparison to CSAS and BSAS might have led to a decrease in milk urea-N.

\section{Rumination and blood metabolites}

The greater ruminating activity for the cows fed diets based on WBC silage than corn silage ( 318.88 vs $283.33, \mathrm{~kg} / \mathrm{d} / \mathrm{head}$ ) might be related to the uNDF intake and physical effective NDF properties between two types of silages. The chewing time $(\mathrm{min} / \mathrm{d})$ of cows fed on $\mathrm{CS}_{U} \mathrm{AS}$ and $\mathrm{BS}_{U} \mathrm{AS}$ was no different in comparison to those fed on CSAS and BSAS, which reflects a lack of significant differences in feed intake (Table 4). Kononoff et al [42] also reported that DMI is an important driver of rumination time. Results of our study indicate that greater water drinking time adjusted per unit of DM and NDF in the cows fed diets based on WBC silage was higher than those fed corn silage might be consisted with initial DM content of silages. The WBC silage had lower DM content than corn silage (Table 3); consequently, the cows fed diets based on the WBC silage spent more time on drinking water to compensate in comparison to those fed corn silage. Ruminating time increased with increasing silage NDF and $\mathrm{uNDF}_{240 \mathrm{~h}}$ intake (Figure 2), which confirms the results of Beauchemin and Buchanan-Smith [43] and Schulze et al [44], who reported that when the NDF concentration in the rations increase, cows and heifers spent more time on chewing. Low UNDF diets based on the $\mathrm{CS}_{\mathrm{U}} \mathrm{AS}$ and $\mathrm{BS}_{\mathrm{U}} \mathrm{AS}$ contained more non-protein nitrogen than untreated high uNDF diets (CSAS and BSAS). This may explain the observations of higher rumen $\mathrm{NH}_{3}-\mathrm{N}$ and the corresponding increases in blood urea-N. Screening alanine aminotransferase in serum is as an indicator for liver function and metabolite status [45]. Increasing alanine aminotransferase in the cows fed diets based on silages containing urea is probably associated with blood urea-N elevation.

\section{CONCLUSION}

The inclusion of urea in the corn and WBC silages and formic acid in alfalfa silage caused improve nutritional value especially via altering NDF characteristic during ensiling. Diet containing low uNDF through the urea applied to corn silages increase milk production. Although replacing the corn silage with the WBC silage did not change feed intake, milk yield was higher in the cows fed diets based on corn silage than those fed WBC silage. Overall, reduction of UNDF by the inclusion of urea and formic acid to silages can affect animal performance. However, more research is required to determination of UNDF in all basic silages and feedstuff additives because of its important to estimation potential digestible NDF and ration formulation to achieve better performance.

\section{CONFLICT OF INTEREST}

We certify that there is no conflict of interest with any financial organization regarding the material discussed in the manuscript. 


\section{ACKNOWLEDGMENTS}

The authors wish to acknowledge the financial support received from the Ferdowsi University of Mashhad, Iran.

\section{REFERENCES}

1. Khan N, Yu AP, Ali M, Cone JW, Hendriks WH. Nutritive value of maize silage in relation to dairy cow performance and milk quality. J Sci Food Agric 2015;95:238-52.

2. Kolver ES, Roche JR, Miller D, Densley R. Maize silage for dairy cows. In: Proceedings of the New Zealand Grassland Association, New Zealand. 2001. p. 195-201.

3. Huhtanen P, Ahvenjarvi S, Weisbjerg MR, Orgaard PN. Digestion and passage of fibre in ruminants. In: Sejrsen K, Hvelplund T, Nielson MO, editors. Ruminant physiology: digestion, metabolism and impact of nutrition on gene expression, immunology and stress. Wageningen, the Netherlands: Wageningen Acad. Publ.; 2006. p. 87-138.

4. Oba M, Allen MS. Effects of brown midrib 3 mutation in corn silage on dry matter intake and productivity of high yielding dairy cows. J Dairy Sci 1999;82:135-42.

5. Raffrenato E, VanAmburgh ME. Development of a mathematical model to predict sizes and rates of digestion of a fast and slow degrading pool and the indigestible NDF fraction. In: Proceedings of Cornell Nutrition Conference for Feed Manufacturers. New York, USA, 2010. pp. 52-65.

6. Cotanch KW, Grant RJ, VanAmburgh ME, et al. Applications of uNDF in ration modeling and formulation. In: Proceedings of Cornell Nutrition Conference. Syracuse, NY, USA, 2014. p. 114-31.

7. Weimer PJ. Why don't ruminal bacteria digest cellulose faster? J Dairy Sci 1996;79:1496-502.

8. McDonald P, Henderson AR, Heron SJE. Microorganisms. The biochemistry of silage. 2nd ed. Kingston, Kent, UK: Chalcombe Publications; 1991.

9. Kung L, Stokes MR, Lin CJ. Silage additives. Agronomy 2003; 42:305-60.

10. Jaakkola S, Kaunisto V, Huhtanen P. Volatile fatty acid proportions and microbial protein synthesis in the rumen of cattle receiving grass silage ensiled with different rates of formic acid. Grass Forage Sci 2006;61:282-92.

11. Harrison JH, Blauwiekel R, Stokes MR. Fermentation and utilization of grass silage. J Dairy Sci 1994; 10:3209-35.

12. Cushnahan A, Mayne CS. Effects of ensilage of grass on performance and nutrient utilization by dairy cattle 1 . Food intake and milk production. Anim Sci 1995;60:337-45.

13. Nagel SA, Broderick GA. Effect of formic acid or formaldehyde treatment of alfalfa silage on nutrient utilization by dairy cows. J Dairy Sci 1992;75:140-54.

14. Mertens DR. Gravimetric determination of amylase-treated neutral detergent fiber in feeds with refluxing in beakers or crucibles: Collaborative study. J AOAC Int 2002;85:1217-40.

15. VanSoest PV, Robertson JB, Lewis BA. Methods for dietary fiber, neutral detergent fiber, and nonstarch polysaccharides in relation to animal nutrition. J Dairy Sci 1991;74:3583-97.

16. NRC. Nutrient requirements of dairy cattle. Washington, DC, USA: National Academy Press; 2001.

17. Lammers BP, Buckmaster DR, Heinrichs AJ. A simple method for the analysis of particle sizes of forage and total mixed rations. J Dairy Sci 1996;79:922-8.

18. Iranian Council of Animal Care. Guide to the care and use of experimental animals. Isfahan, Iran; Isfahan University of Technology; 1995.

19. VanKeulen V, Young BH. Evaluation of acid-insoluble ash as a natural marker in ruminant digestibility studies. J Anim Sci 1977;44:282-7.

20. Sales J, Janssens GPJ. Acid-insoluble ash as a marker in digestibility studies: a review. J Anim Feed Sci 2003;3:383-401.

21. Colenbrander VF, Noller CH, Grant RJ. Effect of fiber content and particle size of alfalfa silage on performance and chewing behavior. J Dairy Sci 1991;74:2681-90.

22. Edmonson AJ, Lean IJ, Weaver LD, Farver T, Webster G. A body condition scoring chart for Holstein dairy cows. J Dairy Sci 1989;72:68-78.

23. Broderick GA, Kang JH. Automated simultaneous determination of ammonia and total amino acids in ruminal fluid and in vitro media. J Dairy Sci 1980;63:64-75.

24. AOAC. Method 990-03. In: Helrich K, editor. Official methods of analysis, first supplement. Arlington, VA, USA: AOAC International; $1990.746 \mathrm{p}$.

25. Playne MJ, McDonald P. The buffering constituents of herbage and of silage. J Sci Food Agric 1966;17:264-8.

26. Deriaz RE. Routine analysis of carbohydrates and lignin in herbage. J Sci Food Agric 1961;12:152-60.

27. Kleinschmit DH, Kung L. A meta-analysis of the effects of Lactobacillus buchneri on the fermentation and aerobic stability of corn and grass and small-grain silages. J Dairy Sci 2006;89: 4005-13.

28. Palmonari A, Gallo A, Fustini M, et al. Estimation of the indigestible fiber in different forage types. J Anim Sci 2016;94:24854.

29. SAS. Statistical analysis system. User's guide: statistics, version 9.2. Cary, NC, USA: SAS Institute; 2003.

30. Kung L. A review on silage additives and enzymes. Newark, DE, USA: Department of Animal and Food Sciences, University of Delaware; 2014.

31. Britt DG, Huber JT. Fungal growth during fermentation and refermentation of nonprotein nitrogen treated corn silage. J Dairy Sci 1975;58:1666-71.

32. Buchanan-Smith JG. Preservation and feeding value for yearling steers of whole plant corn ensiled at 28 and $42 \%$ dry matter with and without cold flow ammonia treatment. Canadian J Anim Sci 1982;62:173-80. 
33. Addah W, Baah J, Groenewegen P, Okine EK, McAllister TA. Comparison of the fermentation characteristics, aerobic stability and nutritive value of barley and corn silages ensiled with or without a mixed bacterial inoculant. Canadian J Anim Sci 2011;91:133-46.

34. Grant RJ, Cotanch KW. Higher forage diets: dynamics of passage, digestion, and cow productive responses. In: Proceedings Cornell Nutrition Conference for Feed Manufacturers. October 16-18, 2012. Syracuse, NY, USA. pp. 45-57.

35. Atrian P, Shahryar HA. Heat stress in dairy cows. Res Zool 2012;2:31-7.

36. Huber JT, Thomas JW. Urea-treated corn silage in low protein rations for lactating cows. J Dairy Sci 1971;54:224-30.

37. Shaver RD, Erdman RA, O'connor AM, Vandersall JH. Effects of silage $\mathrm{pH}$ on voluntary intake of corn silage and alfalfa haylage. J Dairy Sci 1985;68:338-46.

38. Yu P, Refat B, David A. Comparing barley silage with corn silage [Internet]. Christensen for Progressive Dairyman; [cited 2016 September 30]. Available from: https://www.progres sivedairy.com

39. Migliorati L, Boselli L, Pirlo G, Moschini M, Masoero F. Corn silage replacement with barley silage in dairy cows' diet does not change milk quality, cheese quality and yield. J Sci Food
Agric 2017;97:3396-401.

40. Mertens DR. Maximizing forage use by dairy cows. In: WCDS Adv Dairy Technol 2009;21:303-19.

41. Allen MS, Bradford BJ, Oba M. Board-invited review: The hepatic oxidation theory of the control of feed intake and its application to ruminants. J Anim Sci 2009;87:3317-34.

42. Kononoff PJ, Heinrichs AJ, Lehman HA. The effect of corn silage particle size on eating behavior, chewing activities, and rumen fermentation in lactating dairy cows. J Dairy Sci 2003; 86:3343-53.

43. Beauchemin KA, Buchanan-Smith JG. Effects of dietary neutral detergent fiber concentration and supplementary long hay on chewing activities and milk production of dairy cows. J Dairy Sci 1989;72:2288-300.

44. Schulze AKS, Weisbjerg MR, Nørgaard P. Effects of feeding level and NDF content of grass-clover silages on chewing activity, fecal particle size and NDF digestibility in dairy heifers. Animal 2014;8:1945-54.

45. Stojevic Z, Pirsljin J, Milinkovic-Tur S, Zdelar-Tuk M, Ljubic BB. Activities of AST, ALT and GGT in clinically healthy dairy cows during lactation and in the dry period. Vet Arhiv 2005; 75:67-73. 